\title{
Pharmacology and similia principle: indirect secondary counter-regulation. Confirmation from in vitro experiments and classical provings.
}

\author{
Andrea Signorini
}

Fiamo, Rome, Italy

\begin{abstract}
Homeopathy is universally known as an opponent of allopathic Medicine, namely scientific medicine based on ponderal drugs and recognised mechanisms of receptor agonism and antagonism following the dose-response curve. Over time the difficulty to explain with arguments the action of homeopathic ultra-diluted remedies has led many homeopaths to distance themselves from any pharmacological knowledges. Nevertheless this position fortgets not only the modalities in which homeopathy was born and has grown, but a lot of modern changes of view in body-mind communication, cell communication, neuro-immune-endocrinology and bioelectromagnetism, that could give new reasons to treat as clinical homeopathic practice is teaching and to recognize the principle of similars as a modern pharmacological principle. These arguments, receptorial cell communication, bioelectromagnetism and body-mind unity are the bases of Homeopathy and of the Similia Principle and are all included in embryonic but sufficiently clear considerations in the fundamental book of Hahnemann, the Organon (parr. 11, 13, 15-18, 21, 22, 29-32, 63-70). Two kind of evidences confirm the pharmacological bases of Similia Priniciple, in vitro experiments and homeopathic pathogenetic trials on healthy volunteers, best known as provings. Even clinical homeopathic phenomena like initial aggravation and return of old symptoms confirm this pharmacological view of the Simila Principle.
\end{abstract}

Key-words: primary and secondary action, receptors, disease origin, biophysical interactions.

(c)) EY-NC-ND Licensed to GIRI

Support: authors declare that this study received no funding

Conflict of interest: authors declare there is no conflict of interest

Correspondence author: Andrea Signorini, asignorini@tiscali.it

How to cite this article: Signorini AM. Pharmacology and similia principle: indirect secondary counter-regulation. Int J High Dilution Res [online] 2011 [cited YYYY Month dd];10(35):69-69. Proceedings of the XXIV GIRI Symposium;2010 Nov 05; Monte Carlo (Monaco). GIRI; 2010. Available from: http://www.feg.unesp.br/ ojs/index.php/ijhdr/article/view/452/464 